\title{
Value of SPET/CT Image Fusion in the Assessment of Neuroendocrine Tumours with ${ }^{111}$ In-Pentetreotide Scintigraphy
}

\author{
A. Paula Moreira, L. Hugo Duarte, F. Vieira, F. João, J. Pedroso de lima \\ Serviço de Medicina Nuclear. Hospitais da Universidade de Coimbra. Portugal.
}

\begin{abstract}
Summary.-Objective: The purpose of this study was to evaluate the impact and clinical value of anatomical-functional image fusion in the study interpretation and clinical management of patients with neuroendocrine tumours (NET) using somatostatin receptor scintigraphy (SRS) and combined transmission and emission tomography - single-photon emission tomography/CT (SPET/CT).
\end{abstract}

Material and methods: Twelve patients (8 female and 4 male; age range 32-74 y, mean $56 \mathrm{y}$ ) with proven or clinically suspected NET were studied with routine planar SRS and SPET/CT at 2 and 24 hours after injection of $111-222 \mathrm{MBq}{ }^{111}$ In-Pentetreotide. Seven patients came for staging/follow-up and 5 patients for primary tumour localization with staging. Analysis of fused images (SPET/CT) was done on a patient basis, with separated evaluation of SPET, low-dose CT images and fusion images. The gold standard for presence or absence of malignancy was pathology or clinical and imaging follow-up data.

Results: SRS was negative in 6 patients and positive in 6 . SPET/CT provided no additional information in 6 patients, including all 6 negative studies. SPET/CT improved localization of SPET detected lesions in 6 positive studies. It defined the extent of the disease and showed bone involvement in 3 of the 6 positive studies. SPET/CT affected the diagnostic interpretation in 6 patients (50\%) and induced changes of management in $3(25 \%)$.

Conclusion: The results of this study indicate that combined anatomical-functional imaging with SPET/CT significantly improves tumour localization and characterization, contributing to a better therapeutic management of patients with NET.

KEY WORDS: Neuroendocrine tumours. Somatostatin receptor scintigraphy. Image fusion. Anatomic-functional imaging.

\section{VALOR DE LA FUSIÓN DE IMÁGENES DE SPET/TAC EN LA EVALUACIÓN DE TUMORES NEUROENDOCRINOS CON GAMMAGRAFÍA CON ${ }^{111}$ IN-PENTATREÓTIDO}

Resumen.-El objetivo de este estudio fue la evaluación del impacto clínico de la imagen de fusión anatomo-funcional

Recibido: 18-06-04.

Aceptado: 27-08-04.

Correspondencia:

A. Paula Moreira

Serviço de Medicina Nuclear

Hospitais da Universidade de Coimbra

Praceta Prof. Mota Pinto

3000-075 Coimbra. Portugal

E-mail: smnhuc@mail.telepac.pt - apmor@portugalmail.pt en la interpretación gammagráfica y el manejo clínico de pacientes con tumores neuroendocrinos (TNE), utilizando gammagrafía de receptores de la somatostatina (GRS) y tomografia de emisión-transmisión (SPET/TAC).

Material y método: 12 pacientes (8 mujeres y 4 hombres; edad 32-74 años, media 56 años) con TNE diagnosticado o clínicamente sospechado, fueron estudiados con GRS planar y SPET/TAC a las 2 y 24 horas después de la inyección i.v. de 111-222 MBq de ${ }^{111}$ In-Pentatreótido. Siete pacientes fueron valorados para estadificación/seguimiento y 5 pacientes para localización del tumor primario con estadificación. El análisis de las imágenes de fusión (SPET/TAC) se realizó mediante la evaluación de las imágenes de SPET, imágenes TAC de baja dosis e imágenes de fusión. Como referencia para la presencia o ausencia de malignidad se utilizan los datos de la histopatología o la evolución clínica.

Resultados: La GRS fue negativa en 6 pacientes y patológica en 6. SPET/TAC no aportó información adicional en los 6 pacientes GRS negativos. SPET/TAC facilitó la localización de las lesiones detectadas con SPET en los estudios patológicos, aportó mayor información sobre la extensión de la enfermedad y mostró afectación ósea en 3 de los 6 estudios positivos. La SPET/TAC modificó la interpretación diagnostica en 6 pacientes $(50 \%)$ y ha inducido cambios en la decisión clínica y terapéutica en 3 (25\%).

Conclusión: Los resultados de este trabajo inicial indican que la combinación de las imágenes anatómico-funcionales con SPET/TAC mejoran substancialmente la localización del tumor y su caracterización, contribuyendo a un mejor manejo clínico en pacientes con TNE.

PALABRAS CLAVE: Tumores neuroendocrinos. Gammagrafía de receptores de la somatostatina. Fusión de imágenes. SPET/TAC.

\section{INTRODUCTION}

Neuroendocrine tumours (NET) are rare neoplasms corresponding to a very heterogeneous group, which differ in histology, hormone production and clinical behaviour ${ }^{1}$. Nuclear Medicine plays an important role in the management of patients with NET. The outcome of patients with NET is significantly affected by accurate tumour localization and precise determination of the extent of disease. Management of these patients is primarily based on surgical removal of the primary lesion and single 
metastases, as these slow growing tumours are only minimally responsive to systemic chemotherapy. In cases of evidence of multifocal metastatic spread, the differentiated tumour may benefit from treatment with therapeutic doses of cold or radiolabelled ligand ${ }^{2}$. Recent studies indicate that somatostatin receptor scintigraphy (SRS) is more sensitive than sonography, CT, MRI and angiography, for identifying these tumours and their metastases ${ }^{3,4}$. However, the shortcomings of SRS in providing precise anatomical localisation of lesions often necessitate correlation with high-resolution anatomical imaging modalities $^{1,2}$.

SRS is a functional imaging modality based on preferential binding of ${ }^{111} \mathrm{In}$-pentetreotide to somatostatin receptors subtypes II and $\mathrm{V}^{4,6}$. It has the potential to define the extent of metastatic disease, to localize the primary occult tumour site, and to identify the receptor status of metastases for potential octreotide treatment ${ }^{4,6}$. However, the detection of NET remains challenging, due to their usually reduced dimensions and poorly defined anatomic localization. Its specificity may also be affected by tracer uptake at physiological sites or benign conditions. Because of these limitations, SRS may benefit from co-registration with $\mathrm{CT}$, with acquisition of nuclear medicine and CT data during a single imaging session ${ }^{2-5}$. The implementation of these SPET/CT imaging systems has the advantages of minimizing the errors described with co-registration of independently performed studies and optimizing anatomic localization of foci of increased single photon emitting tracer uptake, in addition to a significant improvement in attenuation correction.

The purpose of this study was to evaluate the contribution of hybrid SPET/CT imaging to scintigraphic evaluation, assessing as well fusion related changes and the clinical impact in patients with NET.

\section{MATERIAL AND METHODS}

Twelve patients with proven or clinical suspicion of NET were referred for SRS between February 2003 and January 2004. The patient population included 8 females and 4 males, aged from 32 to 74 years (mean $57 \pm 13$ years).

Seven patients came for staging/follow-up and five came for primary tumour localization with staging (table I).
Scintigraphy was performed after i.v. administration of 111-222 MBq of ${ }^{111}$ In-Pentetreotide (Octreoscan $^{\circledR}$, Mallinckrodt Medical). Planar views and SPET/CT were obtained using a dual head, variable angle gamma camera equipped with a medium energy collimator and a low-dose X-ray CT transmission system, mounted on the same slip-ring gantry (Discovery VH, with CoDe VC \& Hawkeye options, GE Medical Systems). The combined system that provides hybrid functional (SRS) and anatomic (lowdose CT) images allows for acquisition of both procedures in the same setting, without changing the patient's positioning. Planar views were recorded for 15 minutes or up to $500 \mathrm{Kcts}$ from skull to mid-thigh at $2 \mathrm{~h}$ and $24 \mathrm{~h}$ after injection. SPET/CT of abdomen and/or chest and/or pelvis was performed at $24 \mathrm{~h}$ after injection.

For the CT component of the study, a cross-sectional anatomic transmission map was acquired as the system rotated around the patient, with a rotation speed of 2,6 r.p.m.. Each slice acquisition, termed "half-scan" was performed over $240^{\circ}$, taking $16 \mathrm{sec}$. acquisition time for each transaxial slice. The x-ray tube is operated at $140 \mathrm{KVp}, 2,5 \mathrm{~mA}$. Multiple slices were obtained by moving the table by a slice step $(10 \mathrm{~mm})$ before acquiring the next slice. The full field-of-view, consisting of 40 slices, was completed in 10 minutes. The transmission data were reconstructed using filtered back-projection to produce cross-sectional attenuation images in which each pixel represents the estimated attenuation of the imaged tissue. Radiation exposure of the patient following a transmission scan, calculated on the basis of phantom studies, ranged from 1,3-3,5 mGy at the centre to $5 \mathrm{mGy}$ at the surface (CTDIw $=3,54 \mathrm{mGy}$ ).

Following transmission, the emission part of the study was acquired. Acquisition parameters included

Table 1

PATIENTS CLINICAL DATA

\begin{tabular}{lccc}
\hline \multirow{2}{*}{ Tumour type } & \multicolumn{3}{c}{ Indication for SRS } \\
\cline { 2 - 4 } & $\begin{array}{c}\text { Primary tumour } \\
\text { and staging }\end{array}$ & $\begin{array}{c}\text { Staging } \\
\text { follow-up }\end{array}$ & Total \\
\hline Pancreatic & 2 & 3 & 5 \\
Gastrointestinal carcinoid & 1 & 3 & 4 \\
Bronchopulmonary carcinoid & 1 & 1 & 2 \\
Metastatic NET (suspected) & 1 & - & 1 \\
Total & 5 & 7 & 12 \\
\hline
\end{tabular}

SRS: somatostatin receptor scintigraphy; NET: neuroendocrine tumour. 


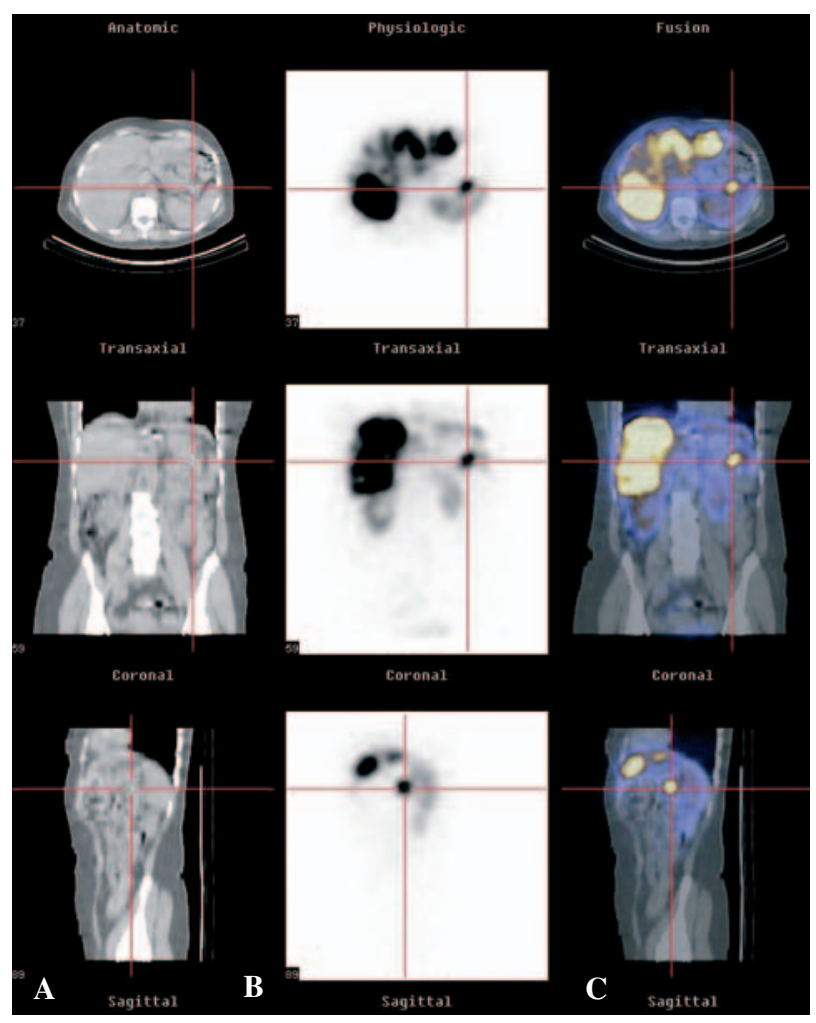

FIG. 1.-Patient with hepatic lesions and a primitive pancreatic NET (marked). A) Low-dose CT images; B) SPET images; C) Fusion images.

a $360^{\circ}$ rotation, $128 \times 128$ matrix, $6^{\circ}$ angle step and acquisition time of $45 \mathrm{sec}$. per frame for a total $33 \mathrm{~min}$ and $45 \mathrm{sec}$. per study. Reconstruction was performed using the ordered subsets expectation maximization (OSEM) technique ( 2 iterations), to avoid the artefacts seen with filtered back projection in areas adjacent to intense tracer activity. The resultant emission images were inherently registered to the anatomical maps. These matching pairs of $\mathrm{X}$-ray and nuclear medicine images were fused using the eNTEGRA workstation software (General Electric Medical Systems) and images of overlying transmission (CT) and emission (SPET) data were generated. Data acquired during SPET/CT were used for anatomic localization of the scintigraphic findings.

SRS, including planar and SPET study were interpreted independently of SPET/CT images by a team of nuclear medicine physicians. Subsequently, data obtained from SPET/CT images analysis were compared to the reports of SRS from the independent analyses. SPET/CT data were confirmed with pathological findings, when available, or with clinical and radiological follow-up, during a 4 to 12 month peri- od. SPET/CT was considered to improve image interpretation once it provided a better localization of sites of increased tracer uptake, or when it excluded disease in sites of physiological or benign tracer uptake. Any change or adjustment in the patient management, whether diagnostic or therapeutic, due to the additional information provided by SPET/CT was recorded.

\section{RESULTS}

Six patients had a negative SRS study, and six had receptor-positive findings.

Among the 6 patients with negative SRS, no further evidence of disease was documented. They included 1 patient with bronchopulmonary NET, 1 patient with rectal NET (excised) and 2 patients with pancreatic NET, who came for staging/follow-up. Two patients with suspected carcinoid came for primary tumour localization and staging. SPET/CT provided no added value to image interpretation and to clinical decision making in all 6 patients with negative SRS.

Among the 6 patients with positive SRS, disease was confirmed pathologically in 2 patients ( 1 by surgery and 1 by bronchoalveolar lavage analysis), radiologically in 5 patients (CT or MRI) and by clinical follow-up in one patient (suspected for insulinoma).

SPET/CT improved the image interpretation in all 6 SRS positive patients ( $100 \%$ of patients with abnormal SRS, and $50 \%$ of the whole group). Of these, SPET/CT contributed to a better anatomic localization in 3 patients, referred for detection of primary tumour and 3 patients who came for staging/follow-up. SPET/CT detected bronchopulmonary tracer uptake (1 patient) and precisely confined tracer uptake in pancreas (2 patients) of 3 patients referred for primary tumour detection. SPET/CT also identified unsuspected bone extension in 2 patients, during follow-up.

SPET/CT results affected patient management in 3 patients, $25 \%$ of the total population and $50 \%$ of the cases where SPET/CT improved image interpretation. It led to a surgical therapeutic approach with chemotherapy in one patient with hepatic lesions in whom was detected a primitive pancreatic NET (fig. 1). In one patient, referred for follow-up after surgery and chemotherapy, SRS-SPET/CT detected bone metastases, which were no responsive to chemotherapy, and was submitted to cold octreotide first in mensal administrations, then weekly and fi- 
nally in continued infusion due to worsening of the general condition (fig. 2). This patient died at 4 months follow-up. In another patient with hepatic lesions referred for primary tumour localization, SPET/CT detected a bronchopulmonary carcinoid (confirmed by bronchoalveolar lavage analysis). This patient was considered not suitable for surgery and was submitted to chemotherapy.

\section{DISCUSSION}

Somatostatin receptors are present on almost all neuroendocrine cells. As a consequence, ${ }^{111}$ In-Pentetreotide scintigraphy has shown a high sensitivity for the diagnosis of both primary and metastatic tumour lesions ${ }^{6,7}$. Although peptide receptor scintigraphy may be useful as a tumour localizing technique in a variety of diseases where it may detect tumour localizations prior to or in addition to conventional imaging, it will never be competitive with, for instance, CT or MRI in anatomic delineation of these disease sites $^{8}$. The incidence of multiple organ involvement in patients with NET is high. The knowledge of the precise extent of disease plays a major role in determining the appropriate treatment option and choice of treatment procedures such as chemotherapy, cytoreductive surgery, embolization, or liver transplantation $^{3}$. Diagnosis of bone metastasis is of prognostic significance, indicating short survival and patients may also be spared unnecessary surgery.

In the present study, fusion of functional and anatomic images obtained sequentially on the same imaging device showed an additional value in the diagnostic capacities of SRS-SPET and CT. SPET/CT improved SRS image interpretation in 6 of the 12 study group patients (50\%), not only due to a more accurate localization of tumour sites but also due to the x-ray based attenuation correction, which results in improved image quality for SPET images. Among these 12 patients, 6 patients were referred for detection of primary tumour and staging and $6 \mathrm{pa}-$ tients were evaluated for extent of disease and for follow-up. The primary tumour was detected in 3 patients ( 2 pancreatic NET and 1 bronchopulmonary carcinoid) and bone involvement in 3. SRS-SPET/CT guided the therapeutic approach in 3 cases $(25 \%)$. The results of our study, evaluating combined SPET/CT in patients with NET are in agreement with the published data.

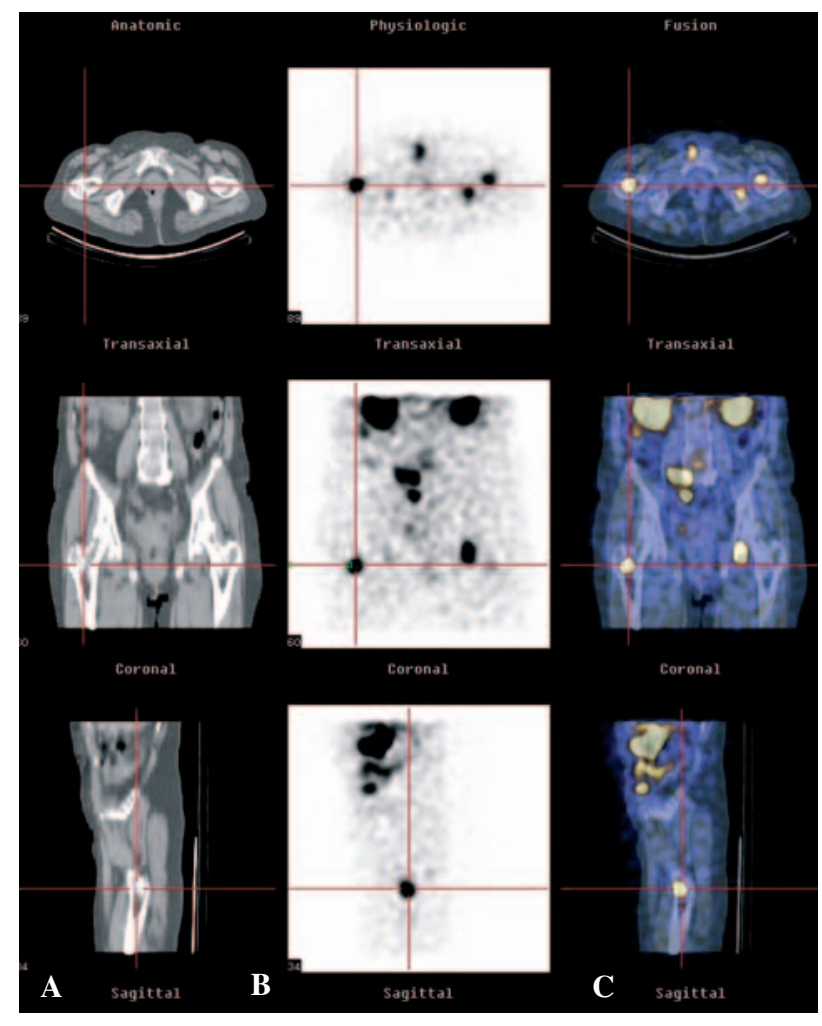

FIG. 2.-SRS-SPET/CT detected new bone metastases, in a patient who was no responsive to chemotherapy, and was submitted to cold octreotide. A lesion in the right femur is shown. A) Low-dose CT images; B) SPET images; C) Fusion images.

\section{CONCLUSION}

The results of this study indicate that the introduction of dual-head gamma camera with an integrated $\mathrm{x}$-ray transmission system (low dose CT) for attenuation correction, anatomical mapping and image fusion, improves image interpretation and provides correct anatomic localization of SRS findings in patients with NET. Hybrid imaging is an accurate, simply achieved method of registration of functional and anatomic data which enhances the already unique role of SRS in the assessment of these tumours. It improves guidance of invasive diagnostic and therapeutic procedures and may help in monitoring therapeutic outcomes.

\section{REFERENCES}

1. Pfannenberg AC, Eschmann SM, Horger M, Lamberts R, Vonthein R, Claussen CD, et al. Benefit of anatomical-functional image fusion in the diagnostic work-up of neuroendocrine neoplasms. Eur J Nucl Med Mol Imaging 2003;30:835-43. 
2. Krausz Y, Keidar Z, Kogan I, Even-Sapir E, Shalom RB, Engel A, et al. SPECT/CT hybrid imaging with ${ }^{111}$ In-pentetreotide in assessment of Neuroendocrine tumours. Clin Endocrinol 2003;59:565-73.

3. Even-Sapir E, Keidar Z, Sachs J, Engel A, Bettman L, Gaitini D, et al.The New Technology of Combined Transmission and Emission Tomography in Evaluation of Endocrine Neoplasms. J Nucl Med 2001;42:998-1004.

4. Krenning EP, Kwekkeboom DJ, Bakker WH, Breeman WAP, Kooij PPM, Oei HY, et al. Somatostatin receptor scintigraphy with ${ }^{111}$ In-DTPA-D-Phe1- and 123I-Tyr3-octreotide: the Rotterdam experience with more than 1000 patients. Eur J Nucl Med 1993;20:716-31.

5. Patton JA, Delbeke D, and Sandler MP. Image Fusion Using an Integrated, Dual-Head Coincidence Camera with X-ray TubeBased Attenuation Maps. J Nucl Med 2000;41:1364-8.
6. Seregni E, Chiti A, Bombardieri E. Radionuclide imaging of neuroendocrine tumours: biological basis and diagnostic results. Eur J Nucl Med 1998;25:639-58.

7. Chiti A, Fanti S, Savelli G, Romeo A, Bellanova B, Rodari M, et al. Comparison of somatostatin receptor imaging, computed tomography and ultrasound in the clinical management of neuroendocrine gastro-entero-pancreatic tumours. Eur J Nucl Med 1998;25:1396-403.

8. Krenning EP, Kwekkeboom DJ, Pauwels S, Kvols LK, Reubi JC. Somatostatin Receptor Scintigraphy. En: Freeman LM, editor. Nuclear Medicine Annual 1995. New York: Raven Press, 1995; p. $1-50$.

9. Keidar Z, Israel O, Krausz Y. SPECT/CT in Tumor Imaging: Technical Aspects and Clinical Applications. Semin Nucl Med 2003;33:205-18. 